PERINATAL LESSONS FROM THE PAST

\title{
Gregor Mendel, OSA (1822-1884), founder of scientific genetics
}

\section{P M Dunn}

Gregor Mendel, an Augustinian monk and part-time school teacher, undertook a series of brilliant hybridisation experiments with garden peas between 1857 and 1864 in the monastery gardens and, using statistical methods for the first time in biology, established the laws of heredity, thereby establishing the discipline of genetics.

$M$ endel, baptised Johannes, was born on 22 July 1822 at Heinzendorf in Moravia, then part of Austria, now in the Czech Republic. He was the only son of struggling peasant farmers who also had two daughters. Initially Mendel attended the village school in Heinzendorf. There, the parish priest, Johann Schreiber, also an expert in fruit growing, recognised his talents and persuaded his parents to continue his education in spite of their limited resources. At the age of 12 he was sent to the gymnasium in Troppau where he studied for the next six years. During that period, Mendel's father was incapacitated by a falling $\log$ and became unable to support his son, whose health in turn suffered. In 1840 Mendel took a two year course of philosophy at the Philosophical Institute of the University of Olmütz, but having passed the final exams in mathematics and Latin philosophy with the highest grades, he withdrew because of ill health. At this point in 1842, his younger sister came to his aid with financial support while he completed an extra year's study. His exam results were excellent, especially in mathematics and physics. In 1843 at the age of 21, Mendel entered the Augustinian Order at St Thomas Monastery near Brünn (now Brno), took the name of Gregor, and began his theological studies at the Episcopal Seminary there. He was ordained to the priesthood in 1847. The role of the parish priest at that time in Austria extended way beyond the care of men's souls. St Thomas Monastery was a centre of creative interest in both science and culture, having among its members well known philosophers, musicians, mathematicians, mineralogists, and botanists. During this period, Mendel was able to study agriculture, fruit growing, and viniculture as well as theology. ${ }^{1-3}$

After ordination, Mendel was assigned first to pastoral duties, and then, finding himself unsuited to this because of his shyness, to teaching in a secondary school in Znaim. However, on failing to obtain his teacher's certificate, he was sent to the University of
Arch Dis Child Fetal Neonatal Ed 2003;88:F537-F539

Vienna (1851-1853) to study natural sciences and mathematics. It was at this time that he acquired the scientific research skills that he was later to put to such good use. In 1854, Mendel returned to teaching in Brünn but two years later again failed to obtain a teaching certificate. It is said that he withdrew from the exam because of nervous exhaustion; another account suggests that it was because of a disagreement with the examiners in botany, a disagreement that then prompted him later to undertake his famous plant breeding experiments. Whatever the truth, this exam failure led to Mendel becoming a parttime assistant teacher, a post that provided him with plenty of time to undertake his scientific research $^{1-3}$ (fig 1).

Between 1857 and 1864 Mendel undertook a series of hybridisation experiments in the Monastery's garden, which were breathtaking for their brilliance in planning, observation, and analysis, and in interpretation of results. He was fortunate to choose the garden pea, Pisum, for his studies because it exists in separate pure lines. Within each line, each plant is identical, although each may vary in characters such as colour or shape. In addition, peas are hermaphrodite, bearing both male and female sex cells on the same individual and able to self fertilise. Furthermore, the flowers are naturally self fertilised before the bud opens and thus before insects can intervene in the process. In addition, the pea is an annual and great numbers can be grown in a small space. Mendel described his project in the following way in the introduction to his paper on Experiments in plant hybridization, which was presented to the Society for the Study of the Natural Sciences in Brünn in $1865^{1-4}$ (fig 2).

\section{Experiments in plant hybridization ${ }^{5}$}

"Experience of artificial fertilization, such as is effected with ornamental plants in order to obtain new variations in colour, had led to the experiments which will here be discussed. The striking regularity with which the same hybrid forms always reappeared whenever fertilization took place between the same species induced further experiments to be undertaken, the object of which was to follow up the developments of the hybrids in their progeny ... so far, no generally applicable law governing the formation and development of hybrids has been successfully formulated of ... 


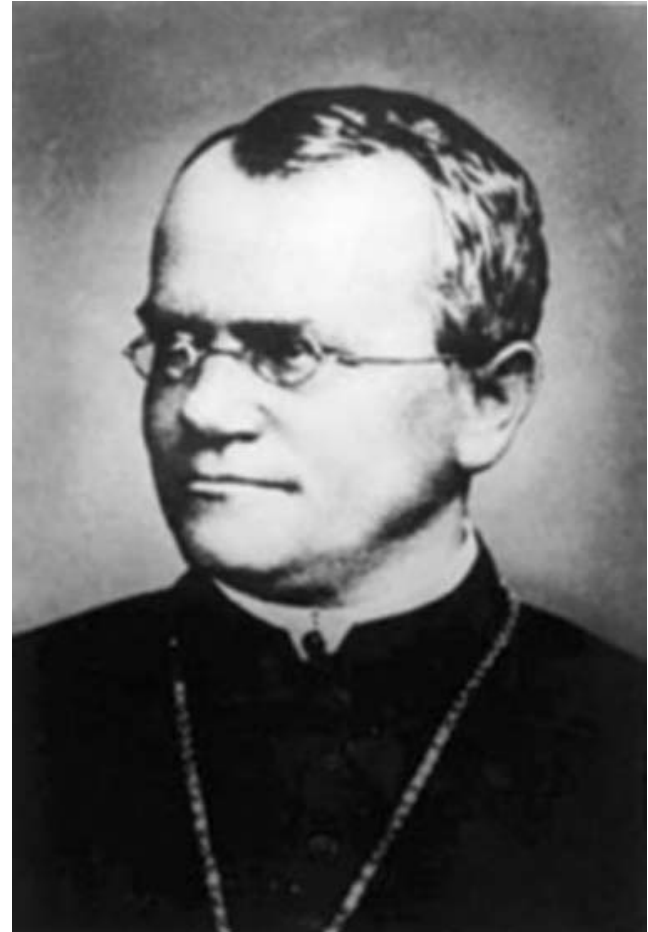

Figure 1 Gregor Mendel, 1822-1884.

Those who survey the work done in this department will arrive at the conviction that among all the numerous experiments made, not one has been carried out to such an extent and in such a way as to make it possible to determine the number of different forms under which the offsping of hybrids appear, or to arrange these forms with certainty according to their separate generations, or definitely to ascertain their statistical relations.

It requires indeed some courage to undertake a labour of such far-reaching extent; this appears, however, to be the only right way by which we can finally reach the solution of a question the importance of which cannot be overestimated in connexion with the history of the evolution of organic forms.

The paper now presented records the results of such a detailed experiment. This experiment was practically confined to a small plant group, and is now, after eight years' pursuit, concluded in all essentials. Whether the plan upon which the separate experiments were conducted and carried out was the best suited to attain the desired end is left to the friendly decision of the reader."

This research did indeed require courage and also persistence and meticulous record keeping. In all, some 10000 plants were grown and observed during the eight year study. The following further extracts from his paper published in 1866 provide a taste of his style and conclusions. ${ }^{5}$

\section{The forms of the hybrids ${ }^{5}$}

"... In the case of each of the seven crosses the hybridcharacter resembles that of one of the parental forms so closely that the other either escapes observation completely or cannot be detected with certainty. This circumstance

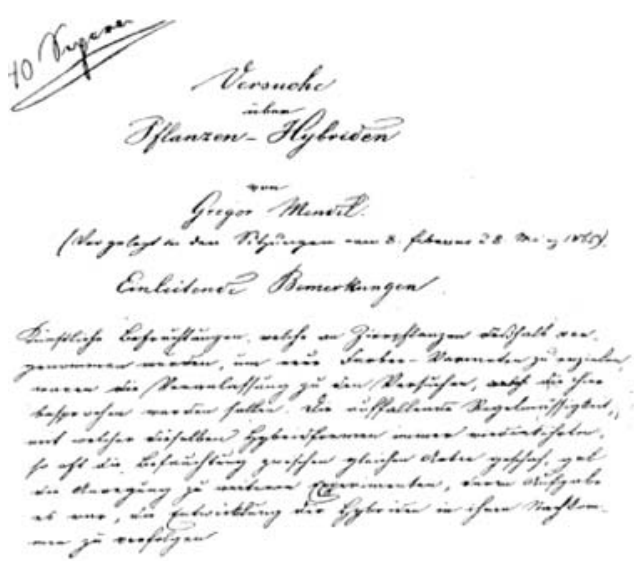

Figure 2 The opening paragraph of Mendel's 1865 paper on the hybridisation of peas.

is of great importance in the determination and classification of the forms under which the offspring of the hybrids appear. Henceforth in this paper those characters which are transmitted entire, or almost unchanged in the hybridization, and therefore in themselves constitute the characters of the hybrid, are termed the dominant, and those which become latent in the process recessive. The expression "recessive" had been chosen because the characters thereby designated withdraw or entirely disappear in the hybrids, but nevertheless reappear unchanged in their progeny, as will be demonstrated later on.

It was furthermore shown by the whole of the experiments that it is perfectly immaterial whether the dominant character belongs to the seed-bearer or to the pollenparent; the form of the hybrid remains identical in both cases ..."

\section{The first generation (bred) from the hybrids ${ }^{5}$}

"In this generation there reappear, together with the dominant characters, also the recessive ones with their peculiarities fully developed, and this occurs in the definitely expressed average proportion of three to one, so that among each four plants of this generation three display the dominant character and one the recessive. This relates without exception to all the characters which were investigated in the experiments. The angular wrinkled form of the seed, the green colour of the albumen, the white colour of the seed-coats and the flowers, the constrictions of the pods, the yellow colour of the unripe pod, of the stalk, of the calyx, and of the leaf venation, the umbel-like form of the inflorescent, and the dwarfed stem, all reappear in the numerical proportion given, without any essential alteration. Transitional forms were not observed in any experiment...."

"Since the members of the first generation spring directly from the seed of the hybrids, it is now clear that the hybrids form seeds having one or other of the two differentiating characters, and of these one-half develop again the hybrid form, while the other half yield plants which remain 
constant and receive the dominant or the recessive characters (respectively) in equal numbers...."

Before Mendel, heredity had been regarded as a blending process and the offspring a dilution of the various parental characteristics. Mendel showed that the different characters in heredity followed specific laws, which could be determined by counting the diverse kinds of offspring produced from particular sets of crosses. He established two principles of heredity now known as the law of segregation and the law of independent assortment, thereby proving the existence of paired elementary units of heredity (genes) and establishing the statistical laws governing them. In summary, Mendel showed that inheritance depended on the combination of two unequally expressed genes which combined in an individual but never blended. In doing so, he was the first to apply a knowledge of mathematics and statistics to a biological problem.

Although copies of the Proceedings containing Mendel's publication were sent to 133 associations of natural scientists and libraries in a number of countries, and he himself sent reprints to scholars and friends around Europe, there were only three citations of his work in the scientific literature during the next 35 years. Mendel in fact paid the price for being too far in advance of his time.

In 1868, the Abbot of St Thomas' died and Mendel at the age of 46 was elected to succeed him as spiritual director of the monastic community. He was clearly well liked and respected by his fellow monks for his honesty, loyalty, and modesty. However, from that time on he was overwhelmed by administrative and public service duties. In particular, he became very involved in fighting, unsuccessfully, the government on a new law to tax the monastery. In addition, he became a member of the Moravian legislature and was greatly in demand in numerous fields, religious, literary, agricultural, horticultural, humanitarian, and educational. Among the 34 societies of which he was an active member were the Austrian Zoological-Botanical Society, the Austrian Meteorological Society, the Moravian Apiary Society, and the Imperial-Royal Moravian-Silesian Agricultural Society. At about this time he also developed backache, his eyesight began to fail, and he became overweight. He published only one further scientific paper, on hawkweed in 1869. It was of little significance. In his own words he had to "neglect completely his experimental work with plants". He became a rather solitary figure. Towards the end of his career he wrote: "I have experienced many a bitter hour in my life. Nevertheless, I admit gratefully that the beautiful, good hours far outnumbered the others. My scientific work brought me such satisfaction, and I am convinced the entire world will recognise the results of these studies". The world might, but first there were to be those 35 years of neglect. Only in 1900 did three botanists, Hugo de Vries (Holland), Karl Correns (Germany), and von Tschermac (Austria), independently confirm his work. Meanwhile Francis Galton had in 1897 arrived at a statistical "law of heredity" based on observations on the pedigrees of Basset hounds. Even at the turn of the century, the recognition of Mendel's work aroused a storm of controversy, which lasted a further 35 years. Mendel's use of statistics in biology was original and aroused feelings of intense hostility in certain quarters. There were even accusations that he had been guilty of falsifying his data. By the 1930s, however, the brilliance and correctness of his observations and conclusions on hereditary transmission were universally accepted.

Mendel passed away after a long and painful illness on 6 January 1884. He was 62. Postmortem examination confirmed Bright's disease with secondary hypertrophy of the heart. So died the Right Reverend Abbot Gregor Johann Mendel, mitred prelate and companion of the Royal and Imperial Order of Francis Joseph. He was laid to rest in the Brünn central cemetery. The world has indeed come to recognise him as one of the greatest scientific biologists of all time and the father of genetics.

\section{ENVOI}

Deoxyribonucleic acid (DNA) was identified in 1871. Seventy three years later, Oswald Avery showed that Mendel's particles or genes were entirely made up of this substance. Fifty years ago in 1953 Francis Crick and James Watson announced their discovery of the double helix structure of DNA, which allows the molecule to replicate and hence lay down the blueprint for living organisms and plants. This discovery revolutionised science and gave a great boost to the new discipline of molecular biology. It has led to the Human Genome Project, to genetic screening, to genetic engineering, and to genetic fingerprinting. From the viewpoint of perinatal medicine, it has given rise to the prospect of prenatal genetic diagnosis and gene therapy.

\section{REFERENCES}

1 Weiling F. Historical study: Johann Gregor Mendel, 1822-1884. Am J Med Genet 1991;40:1-25.

2 Sorsby A. Gregor Mendel. BMJ 1965;i:333-8.

3 Walsh RJ. Mendel, man and medicine. Med J Austr 1966;2:917.

4 Jones S. In the blood: God, genes and destiny. London: Flamingo, 1996:18-19.

5 Mendel G. Versuche über Pflanzen-Hybriden. Transactions of Verhandlungen des naturforschenden Vereines in Brünn (1865) 1866;iv:3-270, [Extracts republished. BMJ 1965;i367-74.] 